\title{
EVALUASI KUALITAS AIR PADA HULU TUKAD BADUNG DENGAN METODE STORET
}

I Gusti Ngurah Eka Partama ${ }^{1)}$, Made Sudiarsa ${ }^{2}$, Gede Mahanata Wijaya ${ }^{3)}$

E-mail : epartama@gmail.com ${ }^{1)}$,madesudiarsa@gmail.com²),mahanataw@gmail.com ${ }^{3)}$

1,2) Staf Pengajar Prodi Teknik Sipil Fakultas Teknik UNR Denpasar

3) Alumni Prodi Teknik Sipil Fakultas Teknik UNR Denpasar

\begin{abstract}
ABSTRAK
Sistem DAS merupakan suatu sistem hubungan antara hulu dan hilir, kerusakan yang terjadi di daerah hulu DAS akan mempengaruhi kondisi hulu sampai hilir DAS tersebut. Pada daerah hulu Tukad Badung terdapat cukup banyak pemukiman padat, industri berskala rumah tangga ataupun skala besar. Semakin padatnya penduduk di sempadan hulu Tukad Badung menyebabkan tingginya pencemaran di hulu sungai Tukad Badung. Penelitian ini bertujuan untuk mengetahui kualitas air pada bagian hulu Tukad Badung yang ditinjau secara fisik, kimia dan biologi serta pengklasifikasian mutu air hulu Tukad Badung menggunakan Metode STORET.

Penelitian ini dilakukan dengan mengambil 3 titik lokasi pengambilan sampel air pada Hulu Tukad Badung sepanjang lebih kurang7 km. Sampel air yang diambil diuji di Laboratorium yaitu UPT Lab. Kesehatan Masyarakat Provinsi Bali dan di Laboratorium Bina Medika.Proses pengujian dilakukan sepenuhnya oleh pihak laboratorium dan selanjutnya analisis dilakukan sesuai dengan laporan hasil pengujian laboratorium.

Hasil analisis menunjukkan bahwa nilai rata-rata suhu sebesar 26,87 ${ }^{\circ} \mathrm{C}$, TDS sebesar 129,23 mg/l dan pH sebesar 7,17 yang masih memenuhi seluruh baku mutu yang dipersyaratkan. Untuk nilai rata-rata COD $30 \mathrm{mg} / \mathrm{l}$ dan DO sebesar $4.77 \mathrm{mg} / \mathrm{l}$ hanya memenuhi baku mutu kelas III kemudian nilai rata-rata BOD sebesar $9.64 \mathrm{mg} / \mathrm{l}$ dan faecal coliform sebesar 46000/100 ml, dimana nilai tersebut tidak memenuhi seluruh baku mutu yang dipersyaratkan. Hasil penilaian STORET di daerah hulu Tukad Badung berturut-turut memiliki skor -41 (cemar berat) dibandingkan dengan baku mutu kelas I, skor -35 (cemar berat) dibandingkan dengan baku mutu kelas II, skor -23 (cemar sedang) dibandingkan dengan baku mutu kelas III dan memiliki skor -17 (cemar sedang) dibandingkan dengan baku mutu kelas IV.
\end{abstract}

Kata kunci : Evaluasi, kualitas air, Tukad Badung, STORET

\section{PENDAHULUAN}

Air merupakan sumberdaya alam yang sangat bermanfaat untuk mahluk hidup. Manusia menggunakan air untuk memenuhi segala kebutuhan, seperti keperluan rumah tangga, pertanian, industri, dan lain-lain. Peranan air bagi kehidupan sangatlah penting, sehingga diperlukan perhatian yang besar untuk menjaga sumber air tetap terjaga kualitasnya. Kondisi kualitas air yang diukur dan diuji berdasarkan parameter-parameter tertentu dan metode tertentu berdasarkan perundangundangan yang berlaku. Parameter ini meliputi parameter fisika, kimia dan mikrobiologi. Kualitas air merupakan salah satu indikator dalam pengelolaan Daerah Aliran Sungai (DAS) yang menggambarkan tingkat kesehatannya.

Sistem DAS merupakan suatu sistem hubungan antara hulu dan hilir, oleh karena itu kerusakan yang terjadi di daerah hulu DAS akan mempengaruhi kondisi hulu sampai hilir dan sebagai indikator kerusakannya adalah kualitas air. Air yang memiliki kualitas buruk akan mengakibatkan lingkungan hidup menjadi buruk. 
Tukad Badung merupakan salah satu sungai di Bali yang kondisinya cukup mengkhawatirkan. Semakin padatnya penduduk di sempadan Tukad Badung menyebabkan tingginya pencemaran di sungai Tukad Badung. Terdapat 9 (sembilan) kelompok aktivitas masyarakat di dalam wilayah DAS Badung yang dapat menyumbangkan limbah-limbah domestik dan industri serta mempengaruhi tingkat kualitas air Sungai Badung yaitu aktivitas rumah sakit, aktivitas hotel, pasar, bengkel, pertanian, peternakan, industri pencelupan atau sablon, industri tahu atau tempe, dan aktivitas rumah tangga (Wijana et al., 2010).

Berdasarkan keadaan tersebut terkait pemanfaatannya sebagai air baku atau air minum dan air irigasi maka perlu adanya penelitian di Tukad Badung sehingga diketahui tingkat pencemaran yang terjadi sebagai upaya mewujudkan ketahanan air baku dan air irigasi.

\section{KAJIAN PUSTAKA}

\subsection{Pencemaran Air}

Menurut Peraturan Pemerintah Republik Indonesia Nomor 82 Tahun 2001, Pencemaran air adalah masuknya makhluk hidup, zat, energi atau komponen lain ke dalam air oleh kegiatan manusia, sehingga kualiatas air turun sampai ke tingkat tertentu yang menyebabkan air tidak dapat berfungsi sesuai peruntukannya. Pencemaran air terjadi ketika energi dan bahan-bahan yang dirilis, menurunkan kualitas air untuk pengguna lain Polusi air mencakup semua bahan limbah yang tidak dapat diurai secara alami oleh air. Dengan kata lain, apa pun yang ditambahkan ke air, ketika melampaui kapasitas air untuk mengurainya, disebut polusi. Polusi, dalam keadaan tertentu, dapat disebabkan oleh alam, seperti ketika air mengalir melalui tanah dengan keasaman yang tinggi. Tetapi yang lebih sering menyebabkan polusi pada air adalah tindakan manusia yang tidak bertanggung jawab sehingga polutan dapat masuk ke air (Dini, 2011).

Pencemaran air permukaan dapat mengakibatkan resiko kesehatan. Hal ini disebabkan karena air permukaan atau yang lebih dikenal dengan air sungai tersebut sering digunakan secara langsung sebagai air minum atau sumber air minum. Kekhawatiran juga muncul ketika air permukaan tersebut terhubung dengan sumur dangkal yang digunakan untuk minum air. Selain itu, aliran air sungai memiliki peran penting karena sering digunakan masyarakat sekitarnya untuk mencuci dan membersihkan, untuk pertanian, perikanan, dan untuk rekreasi (Dini, 2011).

\subsection{Parameter Kualitas Air}

Kualiatas air dapat diketahui dengan melakukan pengujian secara fisika, kimia dan biologi. Parameter fisika meliputi pengujian suhu, Total Disolved Solid (TDS) dan kekeruhan, untuk parameter kimia meliputi derajat keasaman (pH), Biological Oxygen Demand (BOD), Chemical Oxygen Demand (COD) dan Dissolved Oxygen (DO), kemudian untuk parameter biologi adalah pengujian Faecal Coliform (KepMen LH No. 115 Tahun 2003) 


\subsection{Metode STORET}

Metode STORET merupakan salah satu metode untuk menentukan status mutu air yang dilakukan dengan membandingkan antara data kualitas dengan baku mutu air sesuai peruntukannya (KepMen LH No. 115 Tahun 2003). Penentuan status mutu air dianalisis dengan metode STORET yaitu dengan menggunakan sistem nilai dari US-EPA (United States-Environmental Protection Agency) dengan mengklasifikasikan mutu air dalam empat kelas, yaitu :

1. Kelas A : baik sekali, skor $=0$, memenuhi baku mutu

2. Kelas B : baik, skor $=-1 \mathrm{~s} / \mathrm{d}-10$, cemar ringan

3. Kelas $\mathrm{C}$ : sedang, skor $=-11 \mathrm{~s} / \mathrm{d}-30$, cemar sedang

4. Kelas D : buruk, skor $\geq-31$, cemar berat

Langkah-langkah penentuan status mutu air dengan menggunakan metoda STORET dilakukan dengan sebagai berikut :

1. Kumpulkan data dari tiap parameter pengujian sampel air, kemudian kelompokkan berdasarkan nilai maksimum,minimum dan rata-rata.

2. Bandingkan data hasil pengukuran dari masing-masing parameter air dengan nilai baku mutu yang sesuai dengan kelas air.

3. Jika hasil pengukuran memenuhi nilai baku mutu air, maka skornya 0 .

4. Jika hasil pengukuran tidak memenuhi nilai baku mutu air, maka diberi nilai seperti Tabel 1.

5. Status mutu air ditentukan sesuai ketentuan US-EPA berdasarkan jumlah skor yang didapat untuk setiap parameter

Tabel 1. Penentuan sistem nilai untuk menentukan status mutu air

\begin{tabular}{|c|l|r|r|r|}
\hline \multirow{3}{*}{ Jumlah Contoh } & \multirow{2}{*}{ Nilai } & \multicolumn{3}{|c|}{ Parameter } \\
\cline { 3 - 5 } & & Fisika & Kimia & Biologi \\
\hline \multirow{4}{*}{$<10$} & Maksimum & -1 & -2 & -3 \\
\cline { 2 - 5 } & Minimum & -1 & -2 & -3 \\
\cline { 2 - 5 } & Rata-rata & -3 & -6 & -9 \\
\hline \multirow{3}{*}{$\geq 10$} & Maksimum & -2 & -4 & -6 \\
\cline { 2 - 6 } & Minimum & -2 & -4 & -6 \\
\cline { 2 - 6 } & Rata-rata & -6 & -12 & -18 \\
\hline
\end{tabular}

Sumber : KepMen LH No. 115 Tahun 2003 


\section{METODE PENELITIAN}

\subsection{Rancangan penelitian}

Secara umum rancangan penelitian ini diawali dengan pemilihan lokasi tempat penelitian lalu selanjutnya pendalaman literatur yang akan digunakan sebagai panduan serta acuan didalam melaksanakan penelitian, kemudian dilanjutkan dengan menentukan tujuan dari pembuatan tugas akhir, pengenalan lokasi untuk mendapat data-data dari mulai survei lapangan yang mencakup data primer dan data sekunder yang mengacu pada peraturan-peraturan yang berlaku, sampai penyusunan laporan sebagai tugas akhir.

Merujuk pada kondisi perairan Tukad Badung yang tercemar limbah, memunculkan ide untuk mengadakan penelitian pada perairan tersebut. Data yang diperlukan berupa data untuk parameter fisika, kimia dan Biologi. Peta DAS Tukad Badung diperlukan untuk menentukan lokasi dan titik pengambilan sampel air. Analisis dilakukan berdasrkan peraturan yang berlaku dan Metode STORET untuk mengetahui status mutu air Tukad Badung.

\subsection{Lokasi Penelitian}

Penelitian dilakukan pada DAS Tukad Badung khususnya pada bagian hulu. Tukad Badung yang memiliki panjang 19,601 km merupakan salah satu sungai yang mengalir dan memasuki Kota Denpasar setelah mengalir melewati Kabupaten Badung. Pengambilan sampel kualitas air dilakukan pada hulu Tukad Badung di Desa Sading, sepanjang $\pm 7 \mathrm{~km}$ menuju wilayah mid-stream Tukad Badung.

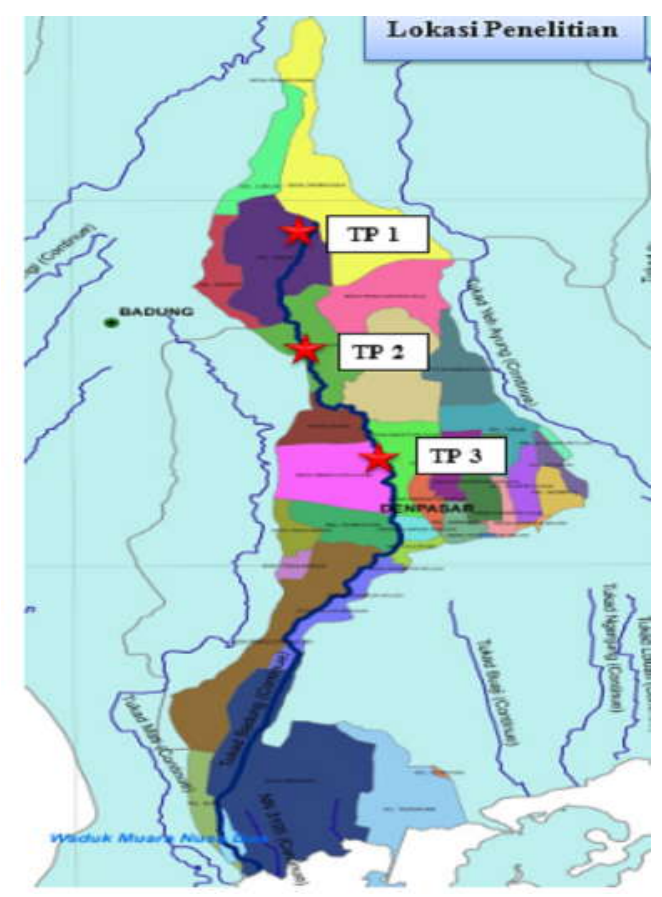

Gambar 1. Lokasi Pengambilan Sampel Air Tukad Badung 


\subsection{Analisa Data}

Analisis data dilakukan dengan pengujian sampel air dengan parameter fisika, kimia, dan mikrobiologi berdasarkan kepustakaan dan peraturan yang berlaku.

Peraturan yang digunakan mengacu pada Peraturan Gubernur Bali No. 16 Tahun 2016 (Pemerintah Provinsi Bali, 2016) tentang Baku Mutu Lingkungan Hidup dan Kriteria Baku Kerusakan Lingkungan Hidup. Untuk mutu air baku, kualitas air Tukad Badung harus masuk pada kriteria mutu air kelas I Pergub Bali No. 16 Tahun 2016 sedangkan untuk mutu air irigasi harus masuk antara rentang kriteria mutu air kelas II - IV karena peruntukannya untuk mengairi pertanaman atau pertanian.

\subsection{Metode Pengujian}

Adapun metode yang digunakan dalam pengujian di masing-masing parameter yang dilakukan disajikan sesuai Tabel 2. Pengujian sampel air diserahkan kepada Laboratoriu Kesehatan Masyarakat Provinsi Bali Laboratorium Bina Medika. Data hasil pengujian di laboratorium digunakan untuk menganalisis status pencemaran dengan menggunakan metode Indeks Pencemaran.

Tabel 2. Parameter kualitas air yang diukur, metode analisis dan alat ukur

\begin{tabular}{|c|c|c|c|}
\hline Parameter & Satuan & M etode Analisis & Peralatan \\
\hline \multicolumn{4}{|l|}{ 1. Fis ika } \\
\hline Suhu & ${ }^{\circ} \mathrm{C}$ & Pemuaian & Thermometer \\
\hline TDS & $\mathrm{mg} / 1$ & Potensiometri & TDS M eter \\
\hline Kekeruhan & NTU & Turb id im etri & Turb id imeter \\
\hline \multicolumn{4}{|l|}{ 2.K im ia } \\
\hline $\mathrm{pH}$ & - & Elek trometri & $\mathrm{pH}$ meter \\
\hline BOD & $\mathrm{mg} / 1$ & Titrim etri wink ler & Peralatan titrasi \\
\hline $\mathrm{COD}$ & $\mathrm{mg} / 1$ & Titrim etrik & Peralatan titrasi \\
\hline DO & $\mathrm{mg} / 1$ & Elektrometri & Do Meter \\
\hline \multicolumn{4}{|l|}{ 3. M ikrobiologi } \\
\hline Fecal coliform & $\mathrm{MPN} / 100 \mathrm{ml}$ & Metode MPN & Tabel MPN, filter \\
\hline
\end{tabular}

Sumber : Laporan pengujian kualitas air oleh Laboratorium Kesehatan Masyarakat Provinsi Bali dan Laboratorium Bina Medika Denpasar

\section{HASIL DAN PEMBAHASAN}

\subsection{Titik Pengambilan Sampel}

Lokasi pengambilan sampel dibagi menjadi 3 titik yaitu : 
a. Titik Pengambilan 1 (STA 0+000) : Br. Pekandelan, Sading, Mengwi, Kabupaten Badung.

b. Titik Pengambilan 2 (STA 3+500) : Br. Dauh Kutuh, Desa Pohgading, Ubung Kaja, Denpasar Utara, Kota Denpasar.

c. Titik Pengambilan 3 (STA 7+000) : Pemecutan Kaja, Denpasar Utara, Kota Denpasar.

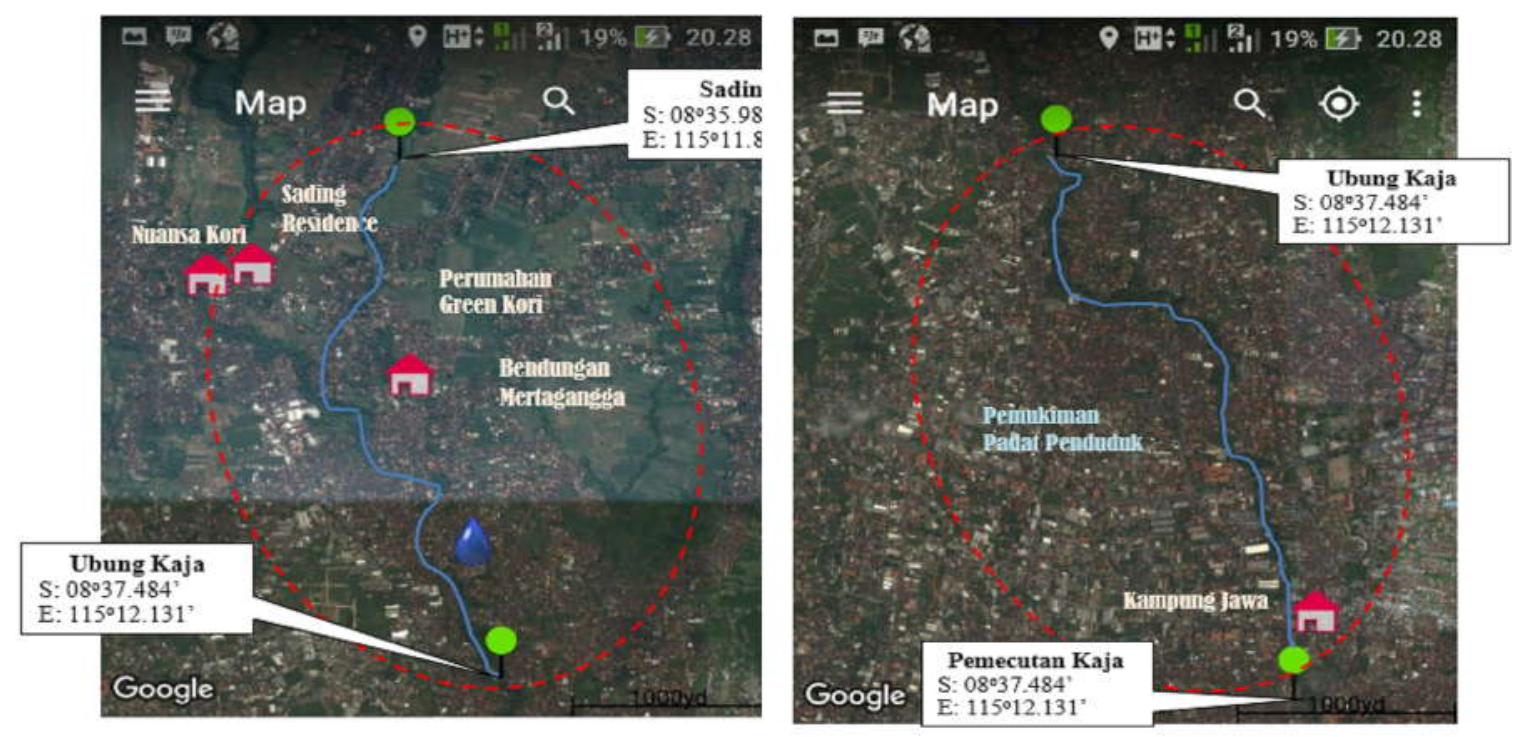

Gambar 2. Lokasi pengambilan sampel

\subsection{Analisis Parameter Kualitas Air}

Tabel 3. Hasil pengujian kualitas air hulu Tukad Badung

\begin{tabular}{|c|c|c|c|c|c|c|c|c|c|c|c|c|}
\hline \multirow[b]{2}{*}{$\mathrm{N}_{0}$} & \multirow[b]{2}{*}{ Panmeter } & \multirow[b]{2}{*}{ Satunn } & \multicolumn{3}{|c|}{ Lokasi\& Kode } & \multicolumn{3}{|c|}{ NihiHasi Pengühn } & \multicolumn{4}{|c|}{ Pergub Ball No. 16 Tahun 2016} \\
\hline & & & Saditg (TI) & $\begin{array}{c}\text { Ubung Kaja } \\
\text { (I2) }\end{array}$ & $\begin{array}{l}\text { Pemecuten } \\
\text { Kaja (B3) }\end{array}$ & Malsinum & Mrimum & Rata-ata & $\begin{array}{c}\text { Balu Metu } \\
\text { Kelas } 1\end{array}$ & $\begin{array}{c}\text { Balu Mitu } \\
\text { Kelas } 2\end{array}$ & $\begin{array}{c}\text { Balu Mete } \\
\text { Kelas } 3\end{array}$ & $\begin{array}{c}\text { Balu Metu } \\
\text { Kelas } 4\end{array}$ \\
\hline $\mathrm{A}$ & \multicolumn{12}{|l|}{ Friln } \\
\hline & Suhn & ${ }^{\circ} \mathrm{C}$ & 26.90 & 26.90 & 26.80 & 26.90 & 26.80 & 26.87 & Deviasi 3 & Deviasi 3 & Deviasi 3 & Deviasi 5 \\
\hline & DS & $\mathrm{ngl}$ & 123.90 & 12290 & 140.90 & 140.90 & 122.90 & 12923 & 1000.00 & 1000.00 & 1000.00 & 2000.00 \\
\hline & Kekeruhan & $\mathrm{NTU}$ & 30.75 & 27.10 & 26.90 & 30.75 & 26.90 & 28.25 & 14.61 & 14.61 & 116.90 & 116.90 \\
\hline $\mathrm{B}$ & \multicolumn{12}{|l|}{ Kimin } \\
\hline & $\mathrm{pH}$ & - & 7.10 & 7.36 & 7.05 & 7.36 & 7.05 & 7.17 & 6.9 & $6-9$ & $6-9$ & 5.9 \\
\hline & $\mathrm{BOD}$ & $\mathrm{ng} 1$ & 11.07 & 3.97 & 13.87 & 13.87 & 3.97 & 9.64 & 200 & 3.00 & 6.00 & 12.00 \\
\hline & $\mathrm{COD}$ & ngl 1 & 40.00 & 10.00 & 40.00 & 40.00 & 10.00 & 30.00 & 10.00 & 25.00 & 50.00 & 100.00 \\
\hline & DO & $\mathrm{ng} 1$ & 5.10 & 6.08 & 3.14 & 6.08 & 3.14 & 4.77 & 6.00 & 4.00 & 3.00 & 1.00 \\
\hline \multicolumn{13}{|c|}{\begin{tabular}{l|l} 
C & Milabbiologi \\
\end{tabular}} \\
\hline & Faecal Coli & $\mathrm{Jm} 1100 \mathrm{mi}$ & $22,000.00$ & $24,000.00$ & $92,000,00$ & 92000.00 & 22000.00 & 46000.00 & 100.00 & $1,000.00$ & $2,000.00$ & 2,00000 \\
\hline
\end{tabular}

Sumber : Laporan pengujian kualitas air oleh Laboratorium Kesehatan Masyarakat Provinsi Bali dan Laboratorium Bina Medika dan Pergub Bali No 16 Tahun 
Analisis untuk menentukan status kualitas air berdasarkan hasil pengujian parameter fisika, kimia, dan mikrobiologi oleh pihak Laboratorium Kesehatan Masyarakat Provinsi Bali dan Laboratorium Bina Medika dengan mengacu pada Pergub Bali No. 16 Tahun 2016.

\subsection{Analisis Parameter Fisika}

Analisis parameter fisika hanya dilakukan berdasarkan hasil pengukuran suhu, Total padatan terlarut dan kekeruhan pada masing-masing titik pengambilan sampel.

\subsubsection{Parameter Suhu}

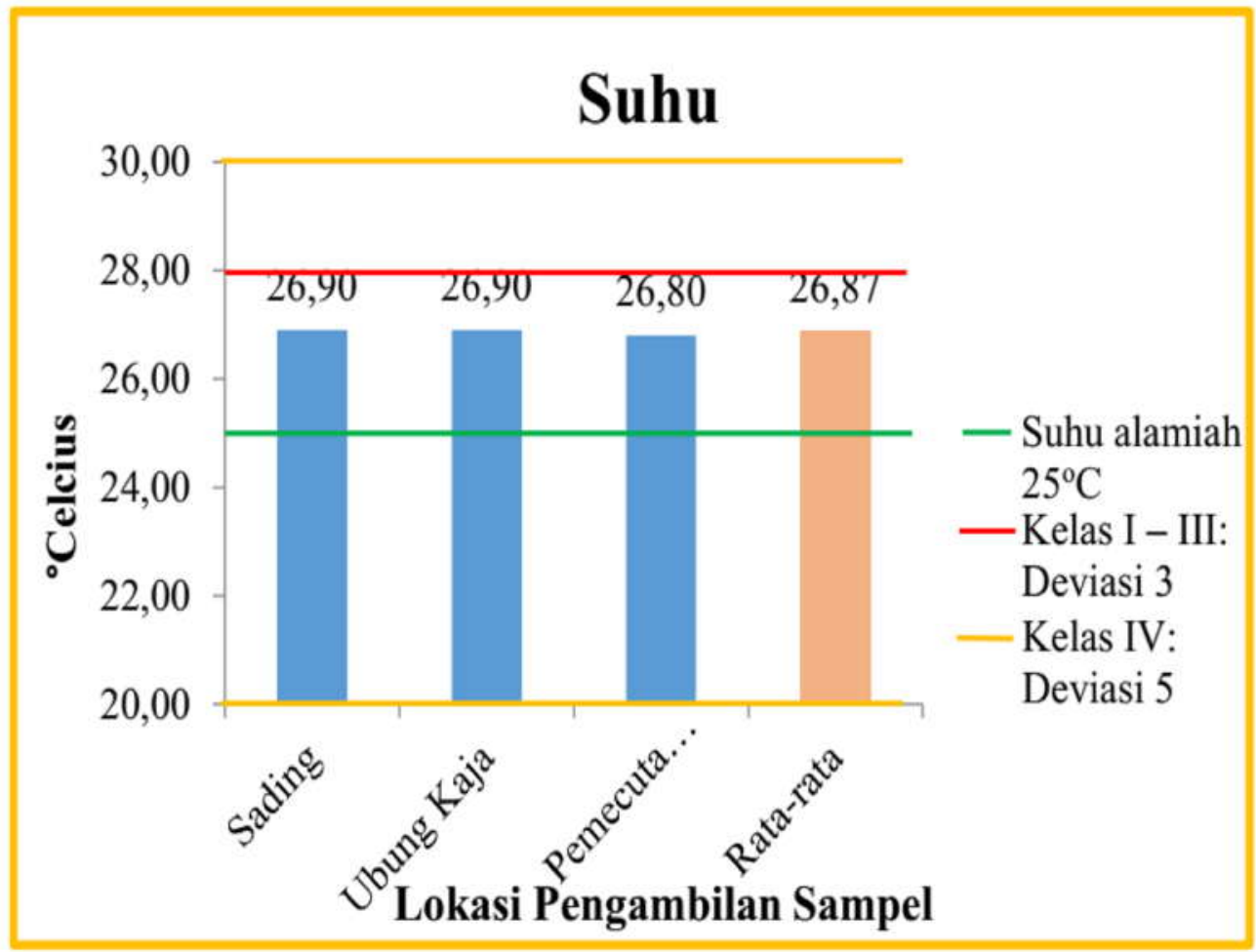

Gambar 3. Hasil pengujian parameter suhu

Hasil pengukuran suhu air di bagian hulu Tukad Badung pada masing-masing titik pengambilan sampel menunjukkan bahwa suhu rata-rata bagian Hulu Tukad Badung adalah sebesar $26.87^{\circ} \mathrm{C}$. Kondisi ini masih sesuai dengan kriteria mutu air kelas I, II, III dan IV menurut Peraturan Gubernur Nomor 16 tahun 2016 yaitu pada deviasi $3^{\circ} \mathrm{C}$ untuk kelas I, II dan III serta deviasi $5^{\circ} \mathrm{C}$ untuk kelas IV dari temperatur alamiahnya yaitu $25^{\circ} \mathrm{C}$.

Nilai TDS dari 3 titik pengambilan sampel menunjukkan fluktuasi, dengan nilai terendah di Ubung Kaja dan tertinggi di Pemecutan Kaja dengan nilai TDS rata-rata sebesar 129.23 mg/1 jauh dari ketentuan maksimum TDS yang ditentukan dalam Pergub No. 16 Tahun 2016 untuk mutu air kelas I, II, III yaitu $1000 \mathrm{mg} / \mathrm{l}$ dan mutu air kelas IV yaitu 2000 mg/l, sehingga masih memenuhi kriteria mutu air kelas I sampai IV 


\subsubsection{Kekeruhan}

ahan-bahan terlarut dalam air dapat menyerap panas yang mengakibatkan suhu air meningkat sehingga jumlah oksigen terlarut dalam air berkurang. Tingginya nilai kekeruhan juga dapat menyulitkan usaha penyaringan dan mengurangi efektivitas desinfeksi pada proses penjernihan air. Nilai rata-rata kekeruhan dari air hulu Tukad Badung sebesar 28.25 NTU atau setara 96,66 mg/l (www.transportation.alberta.ca) telah melampaui batas kelas mutu I dan II tetapi masih dibwah ambang batas kekeruhan kelas mutu III dan IV

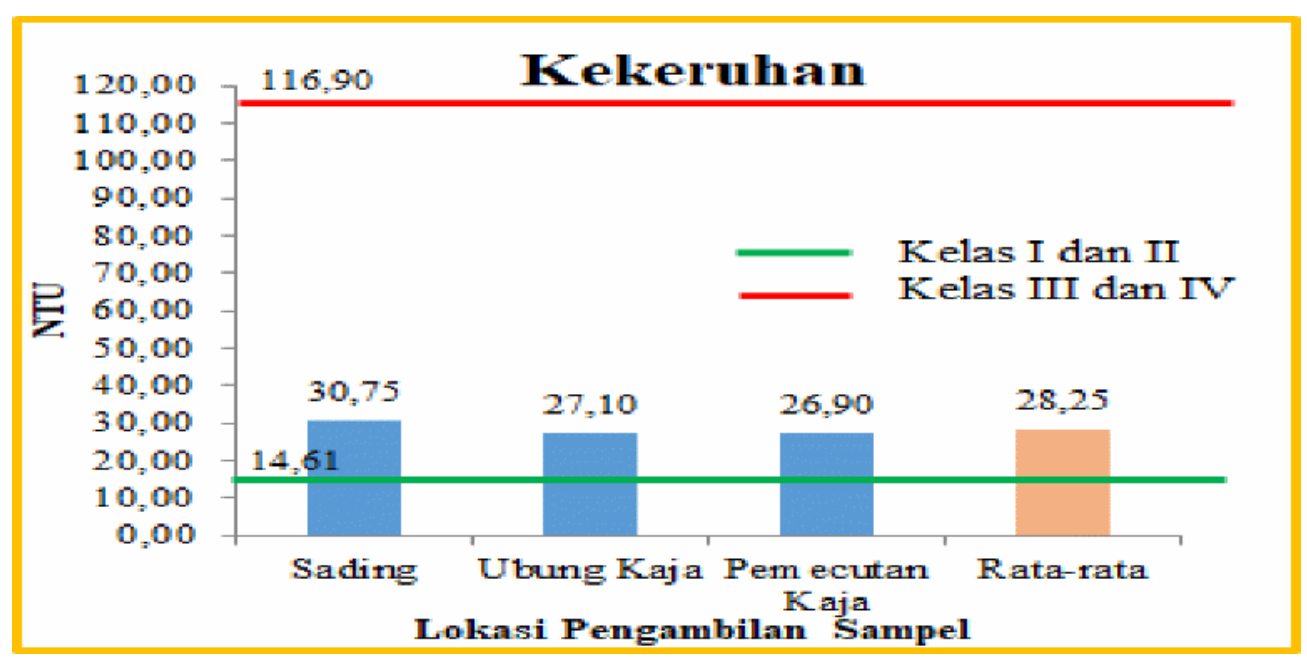

Gambar 5. Hasil pengujian parameter kekeruhan

\subsection{Parameter Kimia}

Parameter kimia yang ditinjau untuk analisis terdiri dari derajat keasaman $(\mathrm{pH})$, kebutuhan oksigen biologi (BOD), kebutuhan oksigen kimia (COD) dan oksigen terlarut (DO).

\subsubsection{Derajat Keasaman (pH)}

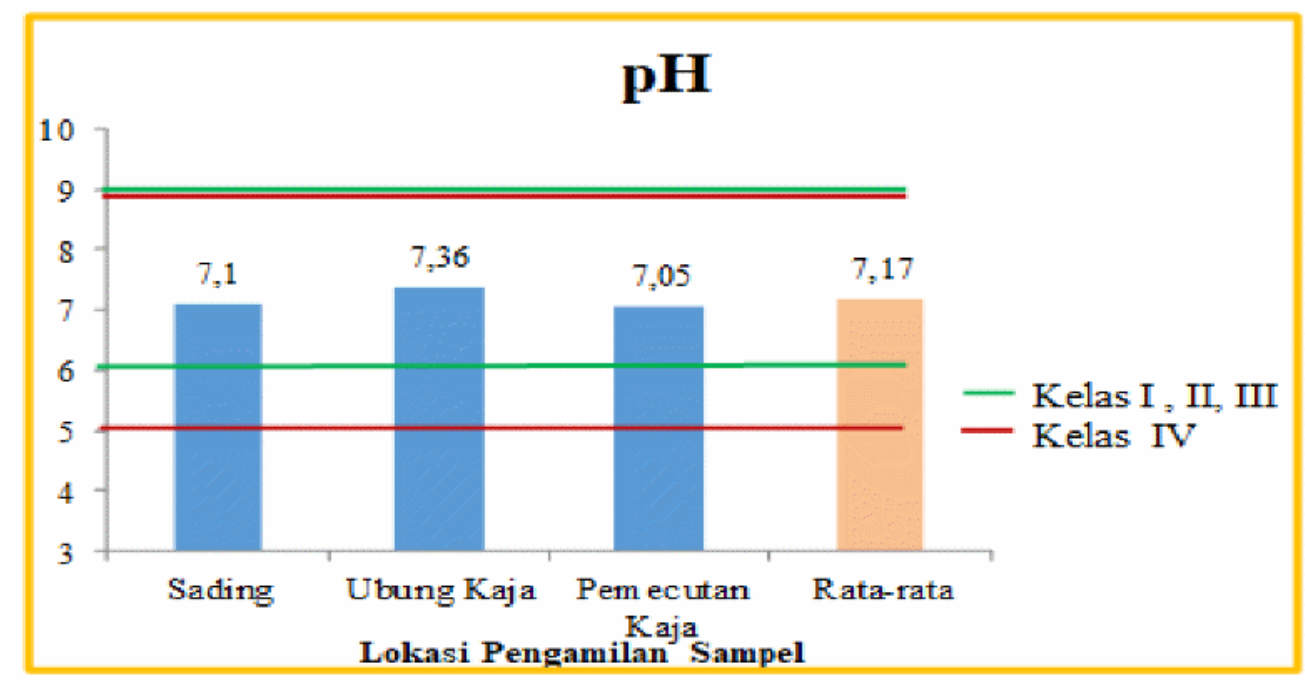

Gambar 6. Hasil pengujian parameter $\mathrm{pH}$ 
Hasil pH air hulu Tukad Badung pada titik I sampai titik III berada pada kondisi sesuai dengan kriteria mutu air kelas I, II, III dan IV yaitu berada pada kisaran 6-9. Rata-rata nilai pH pada hulu Tukad Badung adalah 7.17 sehingga masih memenuhi nilai standar kriteria baku mutu air sungai kelas I, II, III, dan IV.

\subsubsection{Kebutuhan Oksigen Biologi (Biological Oxygen Demand/BOD)}

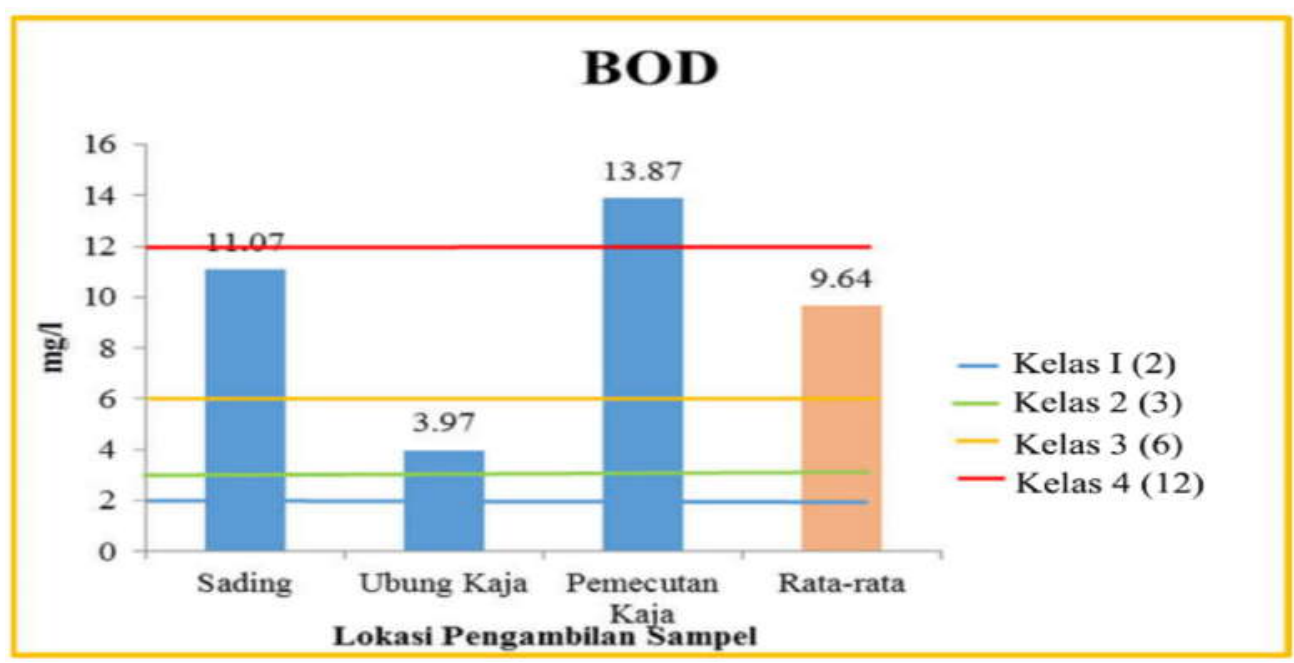

Gambar 7. Hasil pengujian parameter BOD

Nilai BOD bagian hulu Tukad Badung pada titik I sebesar $11.07 \mathrm{mg} / \mathrm{l}$ pada titik II sebesar $3.97 \mathrm{mg} / \mathrm{l}$ dan pada titik III sebesar $13.87 \mathrm{mg} / 1$. Nilai rata-rata BOD pada hulu Tukad Badung sebesar $9.64 \mathrm{mg} / \mathrm{l}$ yang artinya kadar BOD hulu Tukad Badung telah melampaui kriteria baku mutu air untuk kelas I, II, III namun masih memenuhi baku mutu air untuk kelas IV yang mempersyaratkan BOD dengan nilai $12 \mathrm{mg} / \mathrm{l}$.

\subsubsection{Kebutuhan Oksigen Kimia (Chemical Oxygen Demand/COD)}

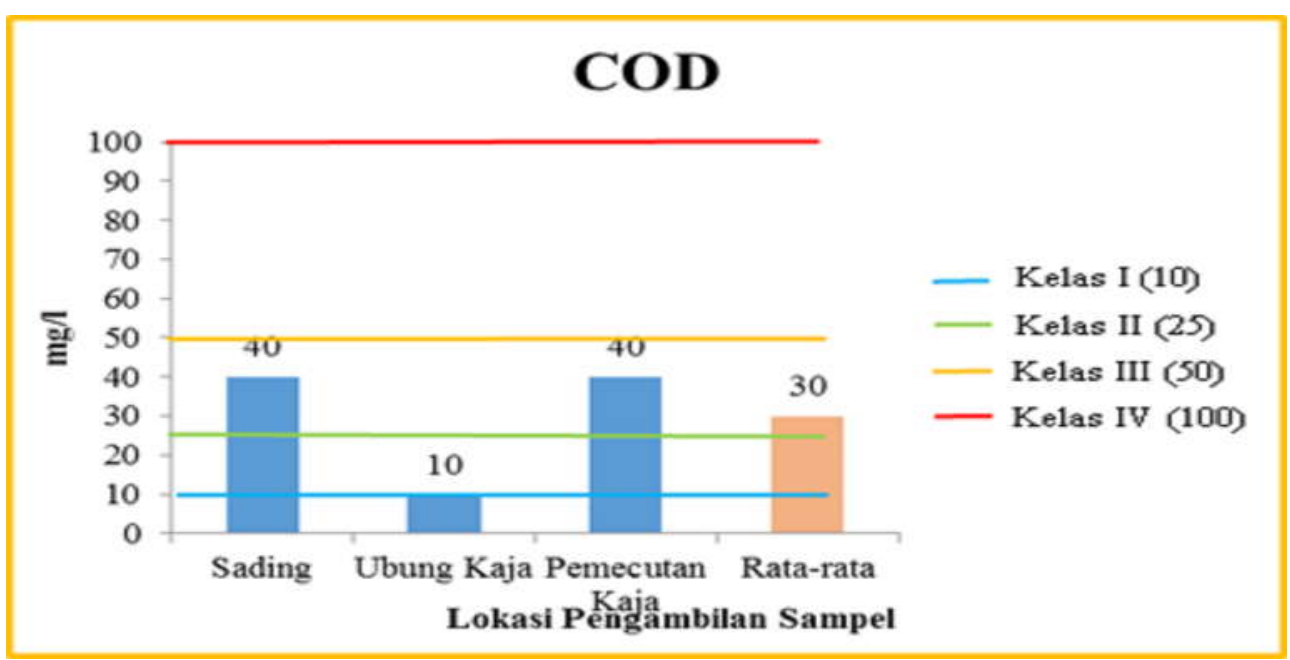

Gambar 8. Hasil pengujian parameter COD 
Nilai Kebutuhan Oksigen Kimia atau COD (Chemical Oxygen Demand) di titik I sebesar $40 \mathrm{mg} / 1$, pada titik II sebesar $10 \mathrm{mg} / 1$ dan titik III sebesar $40 \mathrm{mg} / 1$. Nilai rata-rata pada hulu Tukad Badung sebesar $30 \mathrm{mg} / 1$ dimana nilai ini memenuhi kriteria baku mutu air kelas III dan IV yaitu peruntukan untuk pembudidayaan ikan air tawar, peternakan (Kelas III) dan untuk mengairi pertanaman (Kelas IV).

\subsubsection{Oksigen Terlarut (Dissolved Oxygen/DO)}

Nilai DO pada titik I sebesar $5.1 \mathrm{mg} / 1$, Titik II sebesar $6.08 \mathrm{mg} / \mathrm{l}$ dan titik III sebesar 3.14 $\mathrm{mg} / \mathrm{l}$. Nilai rata-rata pada hulu Tukad Badung sebesar $4.77 \mathrm{mg} / \mathrm{l}$, nilai ini masih memenuhi kriteria baku mutu air sungai kelas III sebesar $3.00 \mathrm{mg} / 1$ dan Kelas IV sebesar $1 \mathrm{mg} / 1$ sehingga bisa digunakan sebagai pembudidayaan ikan air tawar, peternakan, dan mengairi pertanaman atau persawahan.

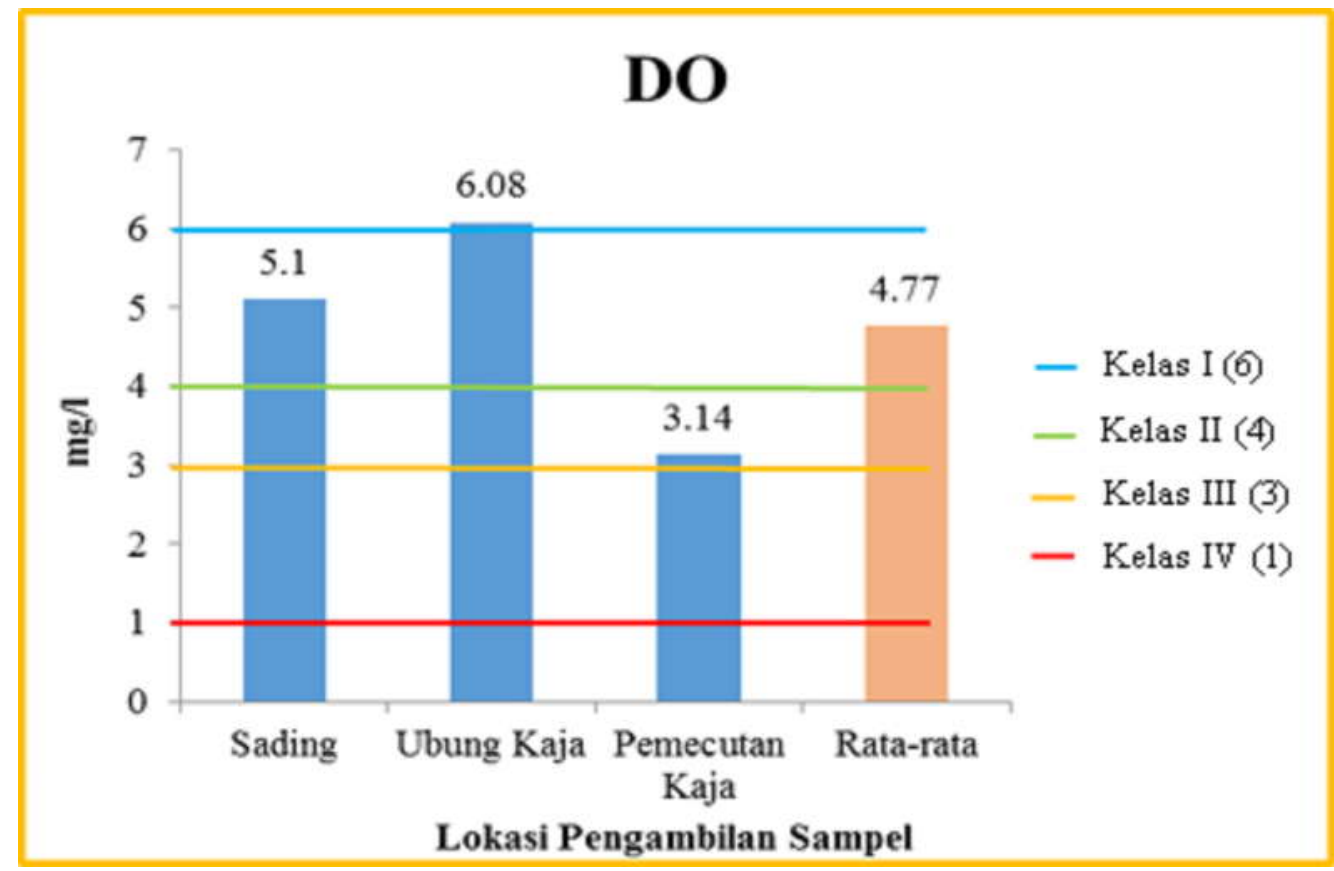

Gambar 9. Hasil pengujian parameter DO

\subsection{Parameter Biologi}

Parameter Biologi yang ditinjau hanya Faecal Coliform dan hasil pengujian secara grafis disajikan pada gambar 10 .

Hasil pengukuran faecal coliform pada air sungai Tukad Badung Bagian hulu menunjukkan jumlah bakteri coliform per $100 \mathrm{ml}$ air sungai, pada titik I sebesar 22,000 MPN/100 ml, titik II sebesar 240,000 MPN/100 ml dan titik III sebesar 92,000 MPN/100 ml. Nilai rata-rata bakteri coliform sebesar 46,000 sehingga melebihi kriteria baku mutu air kelas I, II, III, dan IV. Kondisi ini mengindikasikan air sungai tidak bisa dimanfaatkan untuk air minum. 


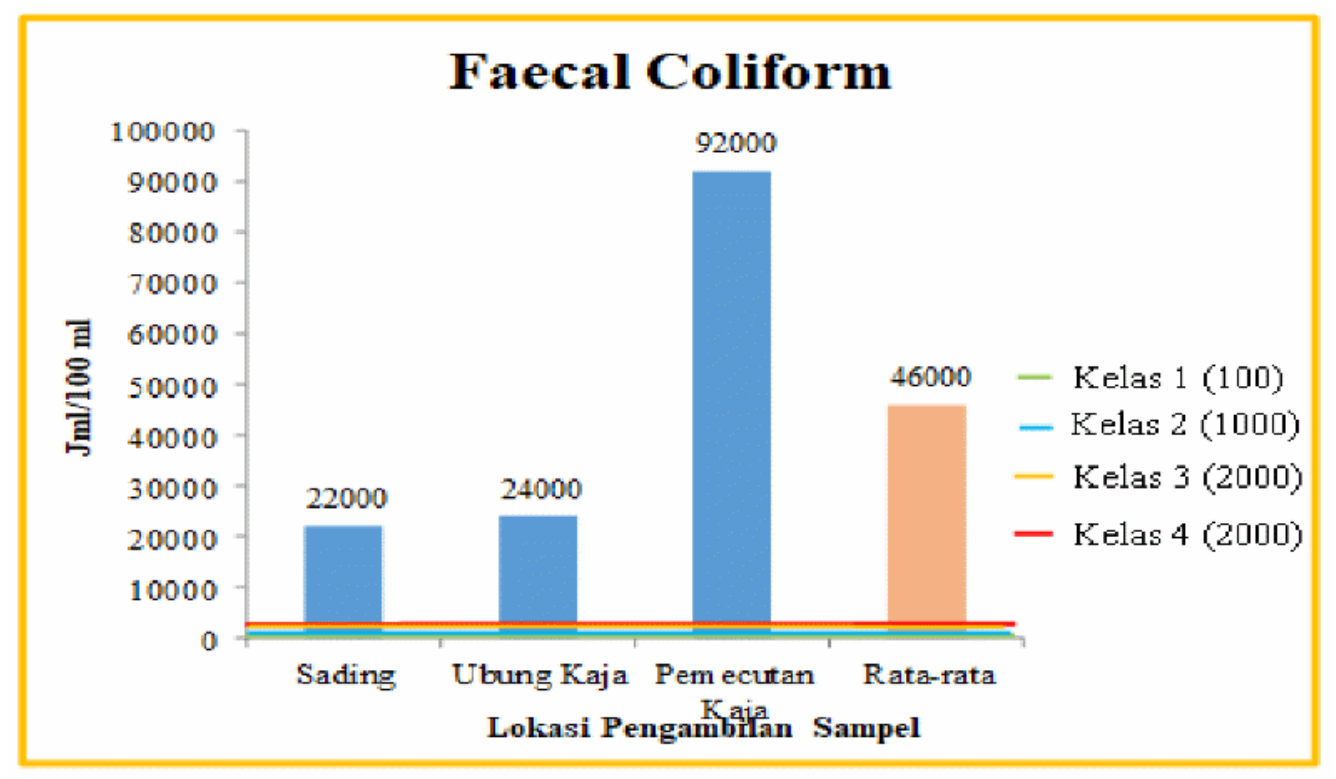

Gambar 10. Hasil pengujian parameter faecal coliform

\subsection{Metode STORET}

Hasil evaluasi kualitas air hulu Tukad Badung berdasarkan indeks STORET ditampilkan pada Gambar 11 dan Tabel 4.

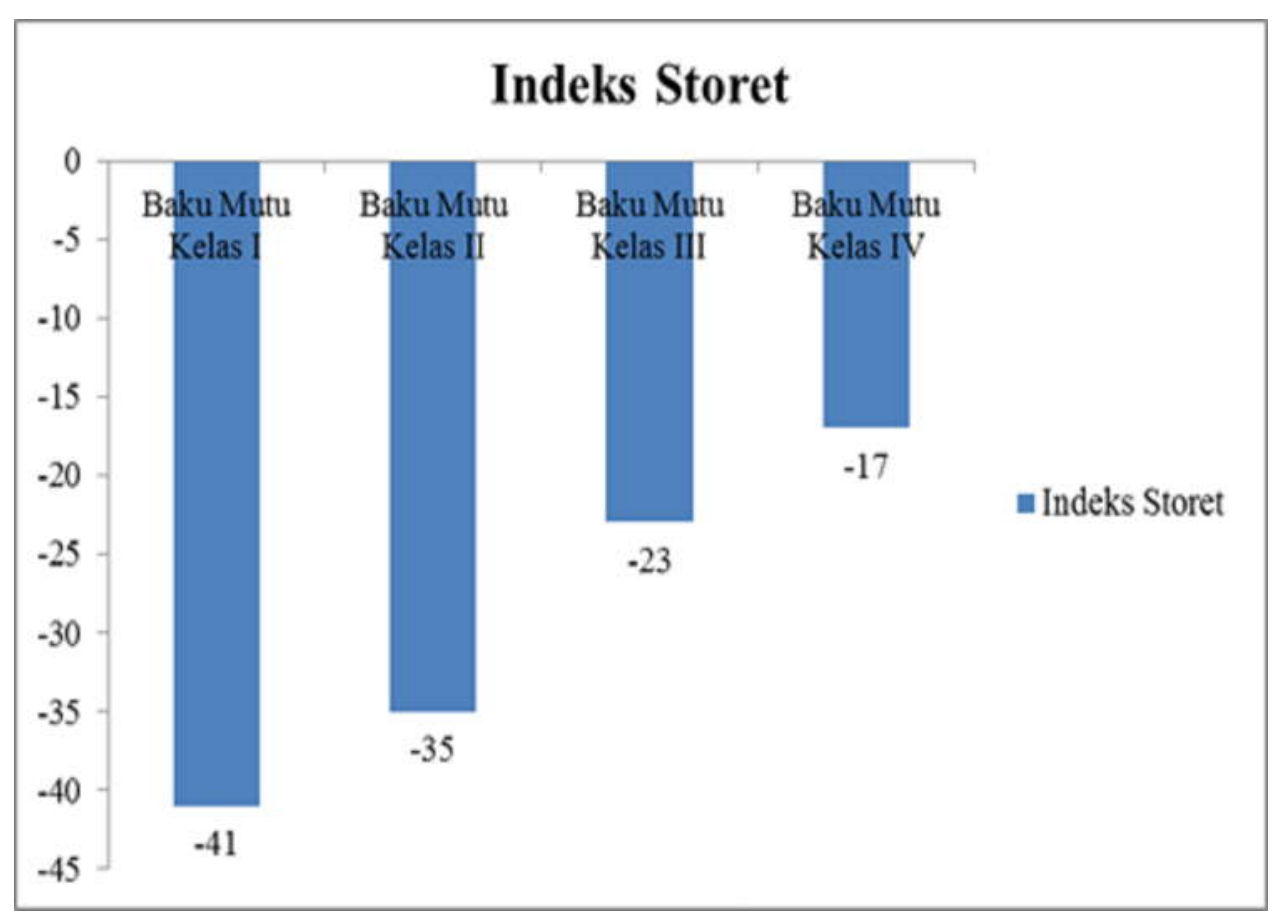

Gambar 11. Grafik Indeks STORET Tukad Badung 
Tabel 4. Status air Tukad Badung beradasrkan Indeks STORET

\begin{tabular}{|c|c|c|c|c|c|}
\hline \multirow{2}{*}{ No } & \multirow{2}{*}{ Lokasi Pengambilan } & \multirow{2}{*}{ Baku Muttu } & \multicolumn{3}{|c|}{ STORET } \\
\hline & & & Skor & Kelas & Kondisi \\
\hline 1 & \multirow{4}{*}{$\begin{array}{l}\text { Hulu Tukad Badung : } \\
\text { Sading, Ubung Kaja dan } \\
\text { Pemectian Kaja. }\end{array}$} & Baku Mutu KelasI & -41 & D & Cemar Berat \\
\hline 2 & & Baku Mutu Kelas II & -35 & D & Cemar Berat \\
\hline 3 & & Baku Mutu Kelas III & -23 & C & Cemar Sedang \\
\hline 4 & & Baku Mutu Kelas IV & .17 & C & Cemar Sedang \\
\hline
\end{tabular}

Sumber : Hasil Analisis

Dari nilai indeks STORET dapat disimpulkan bahwa air hulu sungai Tukad Badung tergolong tercemar berat untuk baku mutu kelas I dan II dan tercemar sedang untuk baku mutu kelas III dan IV. Sehingga pengunaan air hulu Tukad Badung tidak baik digunakan untuk air baku air minum dan sarana/prasarana rekreasi air. Air hulu Tukad Badung yang masih layak digunakan sebagai air irigasi berada di daerah Sading dan Ubung Kaja karena air pada daerah tersebut tidak tercemari berdasarkan parameter fisika dan kimia menurut baku mutu kelas IV. Sedangkan pada daerah Pemecutan Kaja, kondisi air sudah tercemari oleh BOD dimana syarat maksimal BOD berdasarkan baku mutu kelas IV adalah $12 \mathrm{mg} / 1$ sedangkan dari data pengujian diperoleh 13,87 $\mathrm{mg} / \mathrm{l}$.

\section{KESIMPULAN}

Berdasarkan hasil analisis dan pembahasan maka ditarik kesimpulan sebagai berikut :

1. Status mutu air hulu Tukad Badung berdasarkan hasil analisis metode STORET dengan membandingkan pada baku mutu air kelas I, II, III dan kelas IV sesuai ketentuan Pergub Provinsi Bali Nomor 16 tahun 2016 diperoleh :

a. Dibandingkan dengan baku mutu kelas I, diperoleh skor -41 yang berarti hulu sungai Tukad Badung termasuk kelas D dengan kondisi cemar berat (-41 $\geq-31$, cemar berat).

b. Dibandingkan dengan baku mutu kelas II, diperoleh skor -35 yang berarti hulu sungai Tukad Badung termasuk kelas $\mathrm{D}$ dengan kondisi cemar berat $(-35 \geq-31$, cemar berat). 
c. Dibandingkan dengan baku mutu kelas III, diperoleh skor -23 yang berarti hulu sungai Tukad Badung termasuk kelas $\mathrm{C}$ dengan kondisi cemar sedang $(-11 \leq-23 \leq-30$, cemar sedang).

d. Dibandingkan dengan baku mutu kelas IV, diperoleh skor -17 yang berarti hulu sungai Tukad Badung termasuk kelas $\mathrm{C}$ dengan kondisi cemar sedang $(-11 \leq-17 \leq-30$, cemar sedang).

2. Kualitas air hulu Tukad Badung berdasarkan nilai rata-rata dari hasil pengujian parameterparameter kualitas air menunjukkan bahwa :

A. Parameter fisika meliputi pengujian suhu dan TDS.

a. Nilai rata-rata suhu adalah $26,87^{\circ} \mathrm{C}$ yang berarti memenuhi baku mutu kelas I-IV.

b. Nilai rata-rata TDS sebesar $129,23 \mathrm{mg} / \mathrm{l}$ yang berarti memenuhi baku mutu kelas I-IV.

c. Nilai kekeruhan rata-rata 28.25 NTU atau setara $96,66 \mathrm{mg} / \mathrm{l}$ memenuhi baku mutu kelas III dan IV

B. Parameter kimia meliputi pengujian pH, BOD, COD dan DO.

a. Nilai rata-rata $\mathrm{pH}$ sebesar 7,17 artinya nilai $\mathrm{pH}$ hulu Tukad Badung memenuhi baku mutu kelas I-IV.

b. Nilai rata-rata BOD sebesar $9,64 \mathrm{mg} / \mathrm{l}$, memenuhi baku mutu kelas III yang peruntukannya dapat digunakan untuk pembudidayaan ikan air tawar, peternakan, air untuk untuk mengairi pertanaman.

c. Nilai rata-rata COD sebesar $30 \mathrm{mg} / \mathrm{l}$, memenuhi baku mutu kelas II yang diperuntukan untuk prasarana atau sarana rekreasi air, pembudidayaan ikan air tawar, peternakan, air untuk mengairi pertanaman.

d. Nilai rata-rata DO sebesar $4,77 \mathrm{mg} / 1$ yang berarti memenuhi baku mutu kelas I-IV.

C. Parameter biologi meliputi pengujian fecal coliform

Nilai rata-rata fecal coliform yaitu sebesar $46000 \mathrm{jml} / 100 \mathrm{ml}$, nilai ini jauh melampaui seluruh baku mutu yang dipersyaratkan sehingga tidak memenuhi baku mutu kelas I-IV dan tidak bisa dimanfaatkan untuk air minum.

D. Perlu adanya penelitian secara periodik dengan penambahan parameter uji baik parameter fisika, kimia dan biologi untuk mendapatkan gambaran kualitas air hulu Tukad Badung yang lebih detail sehingga pemanfaatannya menjadi optimal.

\section{DAFTAR PUSTAKA}

Dini. S, 2011. Evaluasi Kualitas Air Sungai Ciliwung di Provinsi Daerah Khusus Ibukota Jakarta Tahun 2000-2010, Skripsi, Universitas Indonesia, Jakarta.

http://www.transportation.alberta.ca/Content/docType245/Production/The20conversion\%20of\% 20Nephelometric\%20Turbidity\%20Units.pdf 
Kementerian Lingkungan Hidup, 2003. Keputusan Menteri Negara Lingkungan Hidup No. 115 Tahun 2003 tentang Pedoman Penentuan Status Mutu Air, Jakarta.

Pemerintah Provinsi Bali, 2016. Peraturan Gubernur Bali Nomor 16 Tahun 2016 tentang Baku Mutu Lingkungan Hidup dan Kriteria Baku Kerusakan Lingkungan Hidup, Denpasar

Team Peneliti Tukad Badung, 2015. Analisis Air Tukad Badung di Kota Denpasar, Universitas Udayana, Denpasar.

Wijana, I.M.S., Dewi, I.G.A.K.S.P., As-syakur, A.R., 2010. Studi dan Pemantauan Kualitas Air di Daerah Aliran Sungai (DAS) Badung, Pusat Penelitian Lingkungan Hidup Universitas Udayana, Denpasar. 